\title{
Evaluation of optimum landfill design: Mid Auchencarroch experimental landfill emissions
}

\author{
T. C. Koliopoulos ${ }^{1} \&$ G. Koliopoulou ${ }^{2}$ \\ ${ }^{I}$ Centre of Environmental Management Research, \\ University of Strathclyde, Environmental Consultancy, Greece \\ ${ }^{2}$ Department of Experimental Physiology, Medical School, \\ University of Athens, Greece
}

\begin{abstract}
The produced landfill emissions by waste biodegradation could be exploited after treatment as renewable resources. A comprehensive analysis of the produced landfill emissions is presented taking into account different landfill design principles. In the presented analysis results by the Mid Auchencarroch experimental landfill are taken into account, which is a UK Environment Agency and industry funded research facility. The examining analysis takes into account the entire life cycle of landfill design behaviour in time. The relative magnitudes of pollution load in time by landfill gas and leachate emissions are presented, discussed and evaluated making useful conclusions for the optimisation of future sustainable landfill designs and related regional sustainable development protecting the public health.

Keywords: landfill design, landfill emissions, settlements, landfill topography and spatial analysis, risk assessment, waste management, sustainable development, public health.
\end{abstract}

\section{Introduction}

Sanitary landfills remain an attractive disposal route for municipal solid waste, because, it is more economical than alternative solutions. It is accepted that the landfill biodegradation processes are complex, including many factors that control the progression of the waste mass to final stage quality $[6,9,10,17-19]$. The landfill gas and leachate generation is an inevitable result of the solid waste biodegradation in landfills and their study is necessary for future efficient 
designs, controlling air, soil and groundwater pollution $[2,3,7,12,14-16]$. This paper presents an analysis and modelling of produced landfill emissions versus landfill emissions' pollution load minimisation in time, as a result of change in landfill design.

The use of controlled landfill projects is necessary for quick site stabilisation of landfill emissions, during waste biodegradation. The use of controlled batch anaerobic bioreactors accelerates waste biodegradation in short periods, avoiding any associated environmental risks due to landfill emissions $[1,4,5,8,10]$. Any uncontrolled dumps have to close so as to avoid any threats to the public health and to protect the environment.

Landfilling technologies have been strongly developed in the last decade. Large sanitary landfills are preferred because these provide better opportunities for potential hazard control and an increasing potential for resources' recovery. Efficiently managed sustainable landfill sites can generate considerable volumes of methane gas $\left(\mathrm{CH}_{4}\right)$, which can be exploited by landfill gas recovery installations to produce electricity. The produced landfill gas could be exploited for energy recovery, for greenhouse heating, for biofuel use and for energy supply at several anthropogenic activities of land uses. Also leachate treatment units should be used for water supply in irrigations networks and associated regional development public works, minimizing the use of raw resources.

\section{The case study: Mid Auchencarroch experimental landfill}

This paper analyses the waste biodegradation of Mid Auchencarroch experimental landfill project, which is located next to Alexandria area, between the Loch Lomond and Kilpatrick hills outside from Glasgow city, in Scotland. A comprehensive analysis of the produced landfill emissions is presented taking into account different design principles for an optimum landfill design.

The experimental landfill Mid Auchencarroch is a field scale facility, constructed in order to assess a number of techniques that promote sustainable landfill. Mid Auchencarroch experimental landfill, is an Environment Agency, DTI and industry funded research facility. Mid Auchencarroch (MACH) experimental landfill has been capped since 1995 [10,20].

The experimental variables are waste pretreatment, leachate recirculation and co-disposal with inert material. The project consists of four cells each of nominal plan dimensions $28 \mathrm{~m} \times 30 \mathrm{~m}$ and $5 \mathrm{~m}$ deep, giving a nominal volume of $4200 \mathrm{~m}^{3}$. In figure 1 is presented a cell plan of MACH experimental batch anaerobic landfill bioreactor. In cells 1 and 3 there is pretreatment by wet pulverisation and in cells 2 and 4 the disposed waste is untreated. In cells 1,2 and 3 there is recirculation of leachate and in cell 1 there is addition of inert material $20 \%$ by volume $[10,20]$.

\section{Methods}

The experimental element of MACH project is a test bed for a shallow landfill bioreactor and its control as an enhanced degradation system. A target of this 
project is to show that shallow batch anaerobic landfill bioreactor of municipal solid waste is feasible in terms of establishing and maintaining a suitable environment for methanogenic degradation to occur at significant rates. It is possible to control and enhance landfill gas, heat generation and flush potential leachate and other pollutants from the waste mass, by manipulating the whole process of landfill. Shallow landfill concept can be used as an efficient sustainable sequential batch bioreactor.

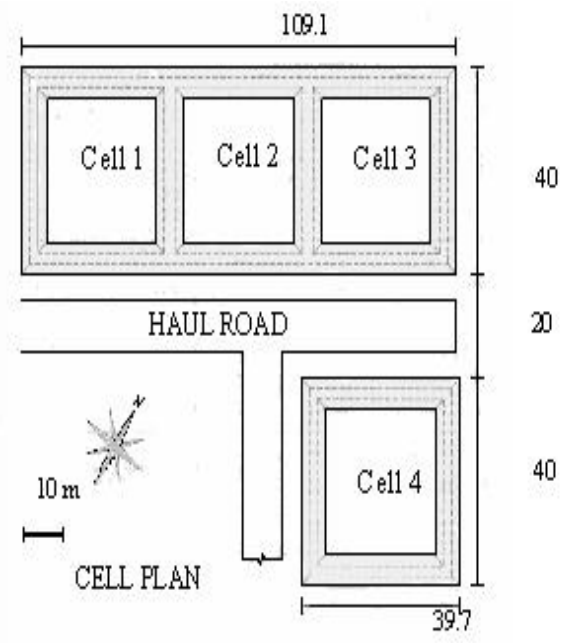

Figure 1: $\quad$ Plan of MACH experimental site.

Careful design and engineering of the cells was considered to be important, so that an effective design was arrived at without excessive construction costs. A drainage blanket there is with $300 \mathrm{~mm}$ thickness on the bottom of the landfill. There is a perforated central well, located in the centre of the waste mass. Also there are thermocouples in vertical direction in the waste mass, which are located next to the centre of the site. A subcap leachate irrigation pipeline system exists and leachate is pumped from the central well. A granular blanket with $150 \mathrm{~mm}$ thickness exists above the five meters of the waste mass for gas collection pipeline, gas flow meter and leachate recirculation pipeline. Also there are settlement survey monuments on the site surface at central and lateral locations. Also a driven temperature probe there is at lateral locations next to landfill boundaries [10].

The gas collection system consists of the top granular blanket, the central well and the gas collection pipeline. The pipeline is $\varnothing 100 \mathrm{~mm}$ perforated twin wall as used for the leachate irrigation and is laid in the top granular blanket. For the same reasons of access as the leachate irrigation pipeline, it is one continuous run without junctions. It is separated from the leachate irrigation pipeline both horizontally and vertically. The gas collection pipeline passes up through the cap 
to a wellhead. Below the wellhead, just above the cap, a $90^{\circ} \mathrm{T}$ junction allows gas into the metering section and hence to the vent. The wellhead is provided because access through the flow metering section is not possible.

Moreover, to measure wastemass temperature, a driven temperature probe was developed with a removable string of thermocouples to allow maintenance or replacement. There are two probes in each cell; one at the centre and one at the periphery. On each thermocouple string there are three thermocouples, near the top, middle and bottom of the wastemass $[10,15]$. The development of the temperature probe is presented below in figure 1 .

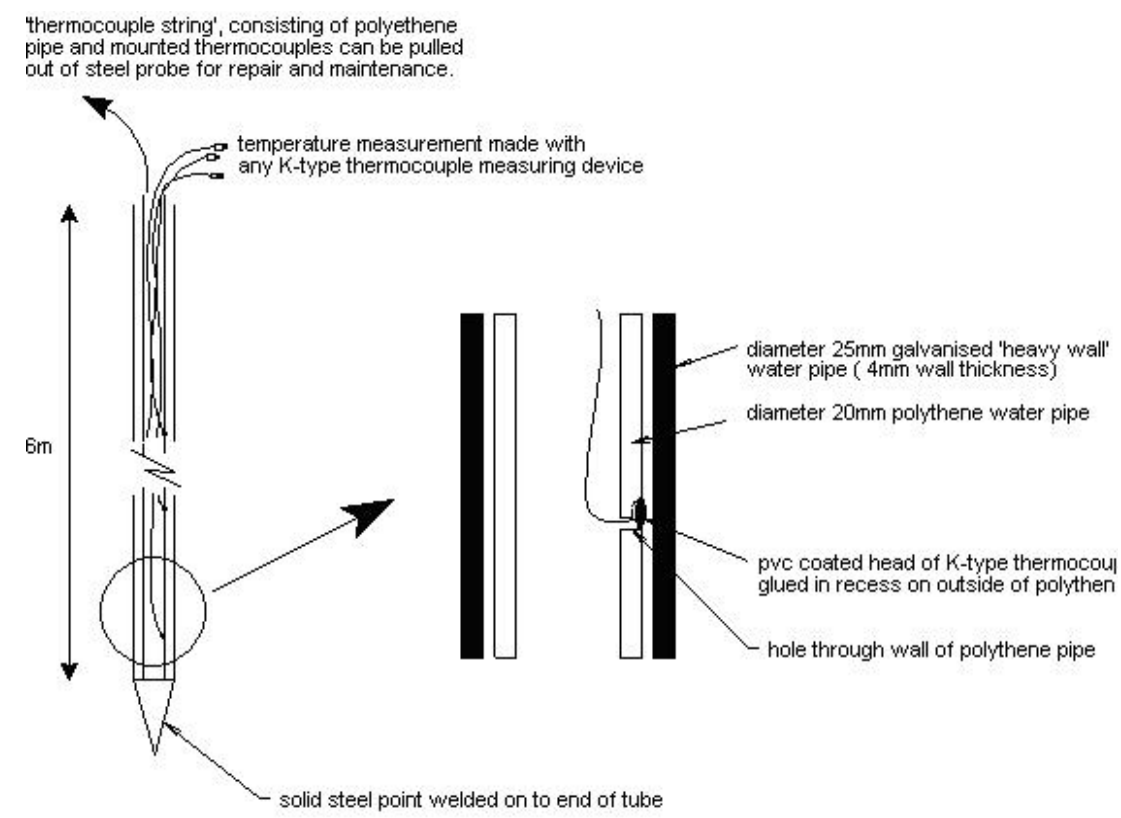

Figure 2: Details of driven temperature probe at Mid Auchencarroch site.

The magnitudes of $\mathrm{pH}$ values, biomass temperature and landfill gas production in time were selected as representative parameters of MACH's site stabilisation making useful conclusions for the optimisation of future sustainable landfill designs and related regional sustainable development protecting the public health and the environment. The examining analysis takes into account the entire life cycle of MACH experimental site behaviour in time.

\section{Results and discussion}

Based on MACH field data a landfill gas production numerical model and associated risk assessment tool was developed with the name SIMGASRISK (SIMulation of GAS RISK). Projections are made of the numerical model SIMGASRISK for landfill gas emissions and waste mass temperature. The 
validation and robustness of SIMGASRISK were based on the measurements of experimental landfill Mid Auchencarroch [10,13,15]. In the next figures are presented the trends of $\mathrm{pH}$ values, biomass temperature in anaerobic degradation and landfill gas production respectively at $\mathrm{MACH}$ experimental cells, based on field data and numerical ones for MACH site $[10,11,13,15]$.

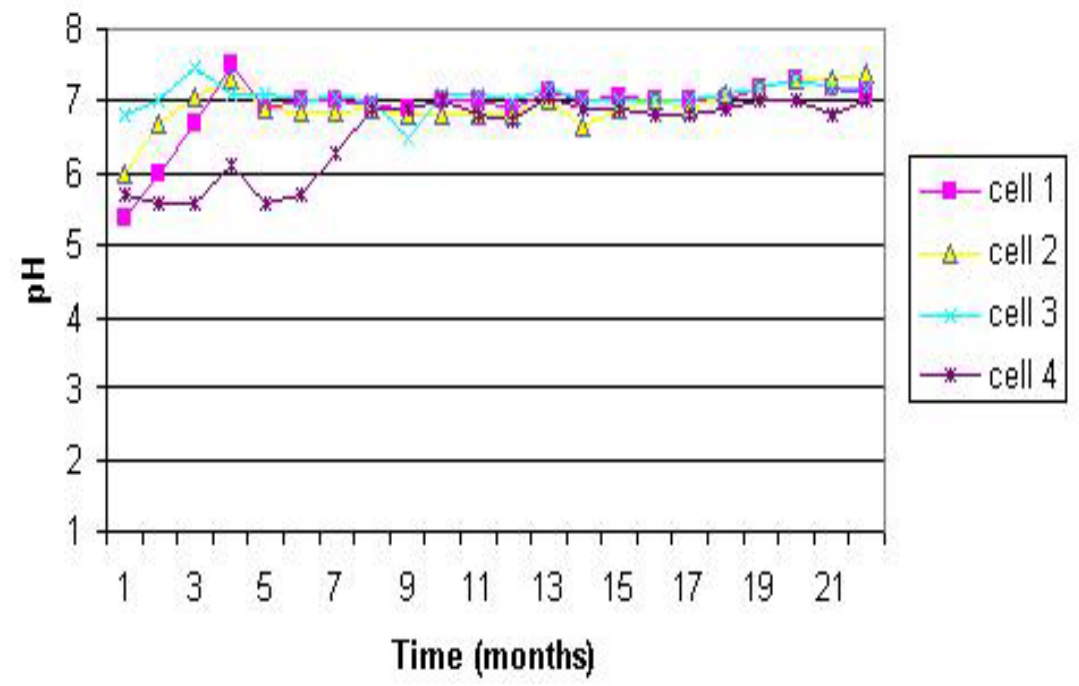

Figure 3: $\mathrm{pH}$ values versus time at $\mathrm{MACH}$ cells.

\section{Biogas production vs Biomass temperature- MACH Cell 1}

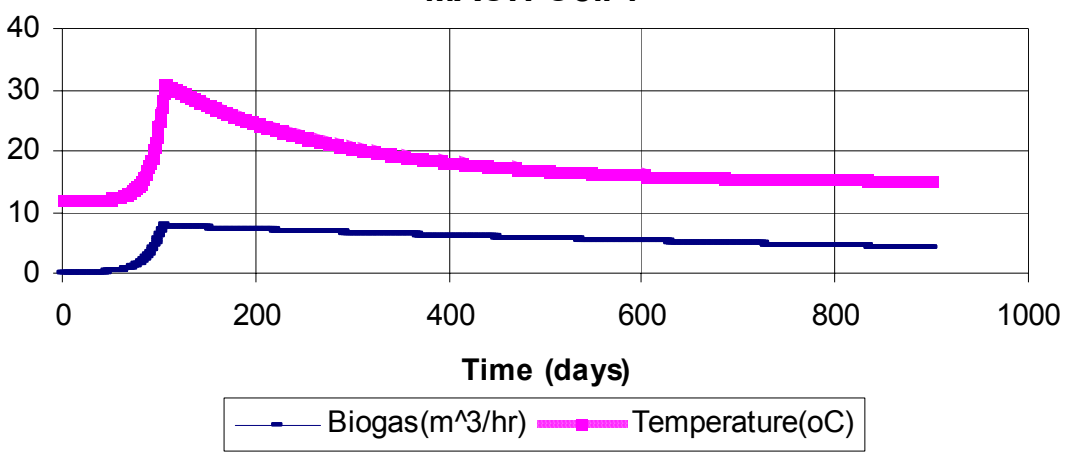

Figure 4: Biogas production versus Biomass temperature at MACH cell 1.

At $\mathrm{MACH}$ cell 3 thermophilic bacteria reached a peak of temperature of $40^{\circ}$ $\mathrm{C}$, which was higher than the rest cells and it presented enhanced anaerobic biodegradation. Also projections are made for the rest $\mathrm{MACH}$ cells. Also the $\mathrm{pH}$ 
values reached a neutral environment in short time period, verifying that $\mathrm{MACH}$ has been stabilised in short time and methanogenesis has been achieved. The use of dynamic models, like SIMGASRISK, are necessary so as to model and analyse biomass biodegration for efficient bioreactor designs and control of particular produced emissions.

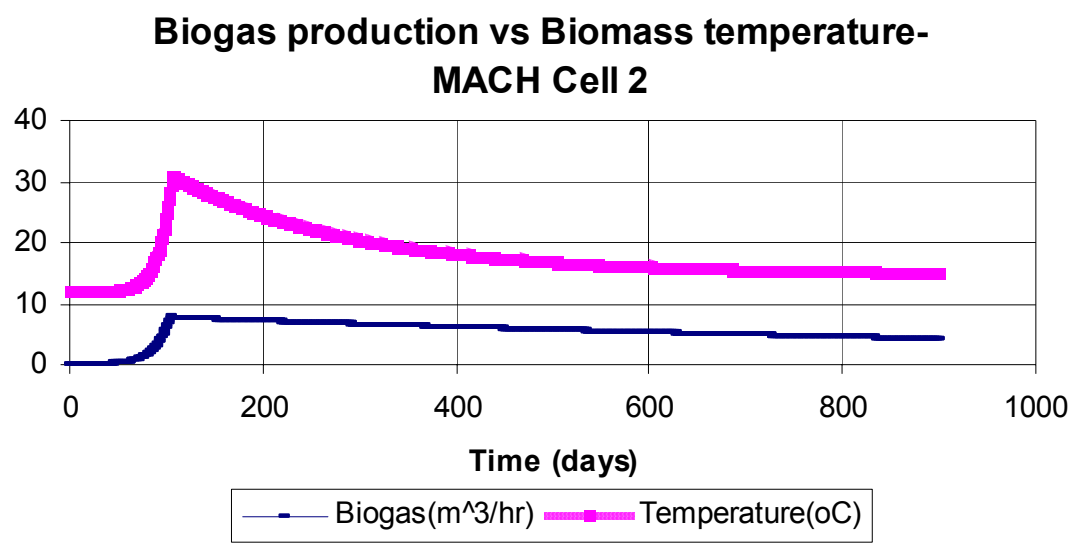

Figure 5: $\quad$ Biogas production versus Biomass temperature at MACH cell 2.

\section{Biogas production vs Biomass temperature- MACH Cell 3}

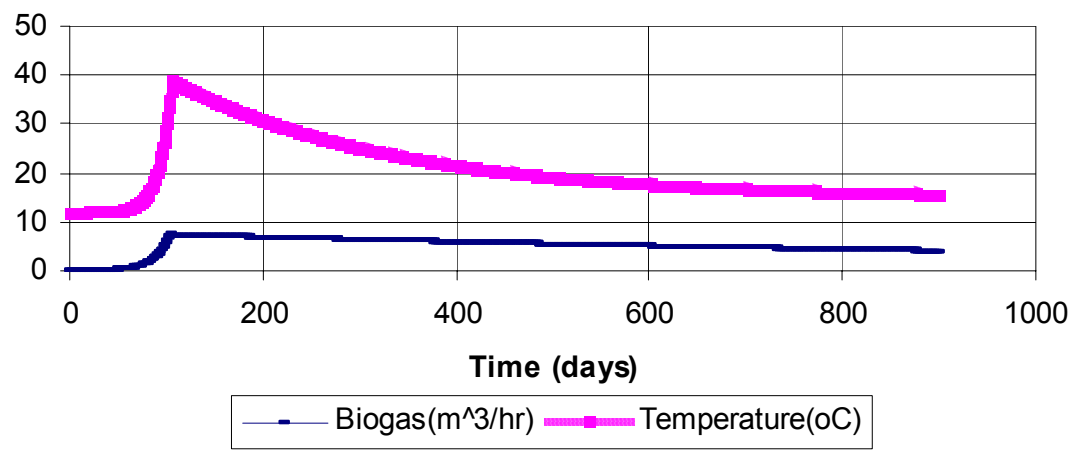

Figure 6: $\quad$ Biogas production versus Biomass temperature at MACH cell 3.

\section{Conclusions}

Development of sustainable sequential batch bioreactors and numerical models of biomass biodegradation are useful so as to make accurate estimations of biomass emissions. MACH's monitoring experimental data and its waste 
biodegradation simulation showed that batch anaerobic bioreactor design is sustainable. MACH site was stabilised in short time avoiding any long term hazardous emissions to the environment and to public health.

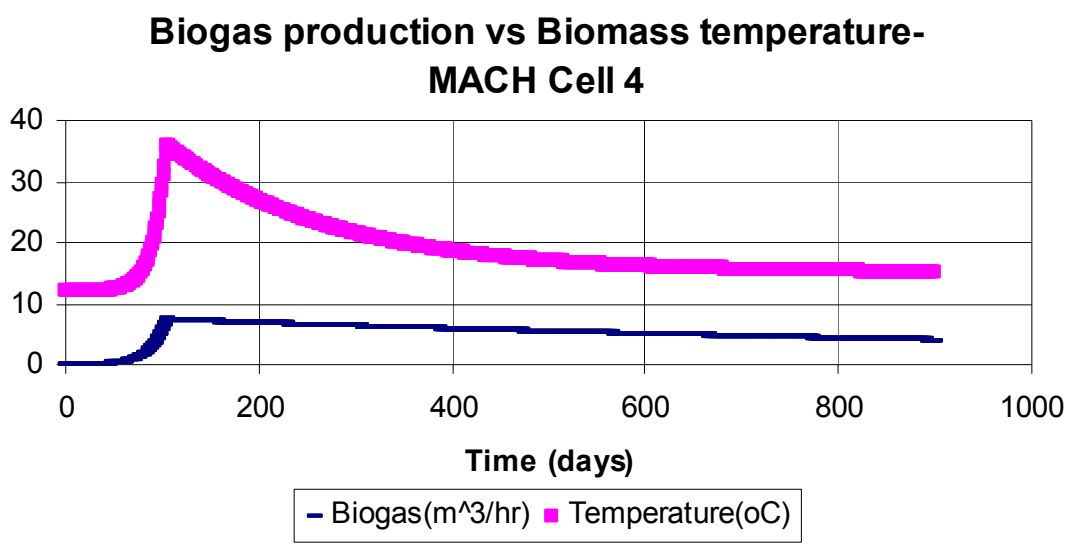

Figure 7: Biogas production versus Biomass temperature at MACH cell 4.

MACH field data showed that an optimum design can be achieved following the principles of cell 1 and cell 3 . Based on MACH field data it was clear that pulverised wet waste, leachate recirculation after treatment accelerate biomass degradation and co-disposal with inert material is sustainable. More field data and case studies are necessary so that optimise landfill design. This will cause control of pollutants protecting public health and exploitation of emissions for renewable resources at several land uses. The installation of a monitoring network at several sites would be useful so as to provide available data for: modelling waste input characteristics; spatial analysis of pollutants in time for a given topography; spatial risk management; communication with the responsible authorities; mapping out rehabilitation works and safe control-confrontation of landfill emissions.

\section{Acknowledgements}

The authors would like to thank Dr. Louise de Rome (ETSU), U.K. Department of Trade and Industry (DTI) and U.K. Environment Agency (EA) for their support of the Mid Auchencarroch experimental project. The conclusions expressed herein represent the findings of the authors and are based on their expertise and experience in this topic area and their findings in the professional literature. It does not necessarily represent the views of EA, or of the participants in the Mid Auchencarroch Experimental Project. 


\section{References}

[1] D.O.E., Waste Management Paper No 27, Landfill Gas, HMSO, London, UK, 1989.

[2] D.O.E., Making Waste Work, White Paper, HMSO, London, UK, 1995.

[3] D.O.E., A guide to risk assessment and risk management for environmental protection, HMSO, London, UK, 1995.

[4] Derby Evening Telegraph, Destroyed Bungalow at Loscoe, Derbyshire, UK Newspaper, 1986.

[5] Elliott, P., Briggs, D., Morris, S., Hoogh, C., Hurt, C., Jensen, T.K., Maitland, I., Richardson, S., Wakefield, J., Jarup, L., Risk of adverse birth outcomes in populations living near landfill sites, $B M J$, 323, pp. 363-368, 2001.

[6] Fleming, G., Monitoring the Methane Gas Generation from Different Classifications of Waste Using the Clay-Waste Sandwich Method of Landfill, CEMS, Glasgow, UK, 1990.

[7] Fleming, G., Hydrogeochemical Engineering in Landfills. In: Geotechnical Approaches to Environmental Engineering of Metals, ed. R. Rudolf, Springer, pp. 183-212, 1996.

[8] Friis, R.H., Sellers, T.A., Epidemiology for Public Health Practice, Jones and Bartlett Publishers, 2004.

[9] Koliopoulos, T.C., Sustainable Solutions for the Most Pressing Problem within Solid Waste Management, International Solid Waste Association Times Journal, 3, pp.21-24, Copenhagen, Denmark, 1999.

[10] Koliopoulos, T.C., Numerical Modelling of Landfill Gas and Associated Risk Assessment, Ph.D. Thesis, Dept. of Civil Engineering, Univ. of Strathclyde, Glasgow, U.K., 2000.

[11] Koliopoulos, T.C., Fleming, G., Modelling of Landfill Gas Production of Treated and Untreated Waste - Mid Auchencarroch, Proceedings of I.S.W.A Congress, vol.2, pp. 1019-1028, eds. G. Kocasoy, T. Atabarut, I. Nuhoglu, Istanbul, Turkey, 2002.

[12] Koliopoulos, T.C., Kollias, V.P., Kollias, P.S. Modelling the risk assessment of groundwater pollution by leachates and landfill gases, Proc. Water Pollution VII: Modelling, Measuring, Prediction, pp. 159-169, eds. C.A. Brebbia, D. Almorza, D. Sales, W.I.T. Press, Southampton, 2003.

[13] Koliopoulos, T.C., Fleming, G. Modelling the biodegradation of treated and untreated waste and risk assessment of landfill gas emissions SIMGASRISK, pp.625-628, Proc. of European Symposium on Environmental Biotechnology, (ESEB), ed. W. Verstraete, Taylor \& Francis Group, Balkema Publishers, Oostende, Belgium, 2004.

[14] Koliopoulos, T.C., Koliopoulou, G. Controlling Landfill Emissions for Environmental Protection: Mid Auchencarroch Experimental Project, Asian J. Exp. Sci., 20(2), pp. 233-242, 2006.

[15] Koliopoulos, T.C., Koliopoulou, G. Evaluating Biomass Temperature vs Biodegradation for Environmental Impact Minimisation: Mid 
Auchencarroch Experimental Landfill, Asian J. Exp. Sci., 21(1), in press, 2007.

[16] Koliopoulos, T., Kollias, V., Kollias, P., Koliopoulou, G., Kollias, S., Evaluation of geotechnical parameters for effective landfill design and risk assessment, Proc. Geotechnical and Environmental Aspects of Waste Disposal Sites, pp. 49-57, eds. R.W. Sarsby, A.J. Felton, Taylor \& Francis Group Pubs, London, 2007.

[17] Kollias, P., Solid Wastes, Lichnos Publications, Athens, Greece, 2004.

[18] Skordilis, A., Waste Disposal Technologies for Non-Hazardous wastes, ION publications, Athens, Greece, 2001.

[19] Tchobanoglous, G., Theisen, H., Vigil, S. Integrated Solid Waste Management, McGraw-Hill Book Company, New York, USA, 1993.

[20] Wingfield-Hayes, C., The Enhanced Landfill Bioreactor: A Sustainable Waste Management Option for the 21st Century? The Mid Auchencarroch Experiments, Ph.D Thesis, Dept. of Civil Engineering, Univ. of Strathclyde, Glasgow, U.K., 1997. 